\title{
The curse and the gift of modernity in late nineteenth-century suicide discourse in Finland
}

\author{
Mikko Myllykangas
}

'In greater nations, where large numbers of people create complicated social situations, where one can find plenty of riches, a lot of suffering, and high intelligence but also many degenerated individuals, the battle against self-murder can at times seem hopeless, and the onlooker is lead to believe it's all caused by grim determinism.' This is how the Finnish physician Fredrik Wilhelm Westerlund (1844-1921) summarised the late nineteenth-century suicide discourse in April 1897. Observing the European debate on suicide from the north-eastern corner of Europe, the geographical distance and especially socio-economic remoteness between Finland and the leading countries of modernisation presented Westerlund with a bird's eye view of the burning question of the connection between suicide and industrialisation, urbanisation, and modern society. Westerlund, like his contemporaries, acknowledged that suicide - the most repugnant of sins for over a thousand years - was a disease brought about by progress, a dark stain that signified a modern society. In this chapter, I explore how suicide as a sign of modernity was interpreted in a country where the material side of modernity - big cities and railroads - were rarely seen by the majority of the population.

The relationship between suicide discourse and modernisation has been a recurring subject in the historiography of suicide since at least the 1980s. The historian Howard Kusher has described in his book SelfDestruction in the Promised Land and subsequent articles how 'the fear of modernity' was reflected in how suicide was conceptualised in the 
nineteenth century. ${ }^{2}$ Yet, however frightening modernisation might have seemed, it was still worth pursuing. For many contemporaries, high suicide rates represented a sign of modernity, an undesirable but at the same time unavoidable price that a society had to pay on its path to the higher reaches of civilisation. While disturbing, the suicide phenomenon was often positioned as something to be proud of; the higher suicide rates in the West were seen as a proof of racial superiority. As Evelyne Leuf notes in her article on Scandinavian suicide statistics, some suicide researchers presented the local suicide figures with often barely disguised pride. ${ }^{3}$ However, this rather widespread conception was not shared by all those who studied the suicide phenomenon in European countries. Towards the end of the century, suicide began to be seen more and more as a symptom of degeneration instead of a sign of increasing mental or cultural sophistication.

In this chapter, I analyse the conflicting views of nineteenth-century suicide researchers as they were faced with the increasing numbers of suicides in societies experiencing modernisation. I point out how local circumstances influenced the way concepts such as modernisation and progress were understood by those who studied suicide. As a historical case, I discuss a suicide study by F. W. Westerlund from 1897, published in 1900. Westerlund's essay 'Själfmorden i Finland' ('Suicide in Finland'), over 150 pages long, shows that suicide research in Finland followed closely in the footsteps of European authors in many ways. In this regard, Finnish suicide researchers viewed (or at least wished to view) their own nation as being part of the modern, civilised world, in which the increasing rates of suicide had become something of a yardstick of progress. However, the local idiosyncrasies of Finnish society also offered Westerlund an outside perspective from which to critically evaluate the established 'truths' about suicide and its connection with the modernisation process. Before examining the suicide discourse of the late nineteenth century, I look at the formation of what could be called 'a modern concept of suicide'.

\section{The shaping of modern suicide}

The difference between the modern conception of suicide and the premodern understanding of suicide is very clear. 'From Satan to Serotonin' and 'From Sin to Insanity': these are just two examples of how 
the historians of suicide (in this case Kushner and Jeffrey R. Watt, respectively ${ }^{4}$ ) have summarised this transition. The two millennia of premodern discourse of suicide were characterised by suicide being understood within the frameworks of philosophy and theology, both of which aimed at answering the question 'is it right or wrong to commit suicide?' In ancient Greek and Roman texts, we can find mythological accounts of suicide followed by both condemnation and apologies for suicide by the philosophers. Whether suicide was regarded as a crime depended on the social status of the actor and the circumstances of the act. ${ }^{5}$ During 'the Middle Age of suicide', beginning around the dawn of the early medieval period, European culture became generally hostile towards suicide, and its criminalisation was backed by theological condemnation. The only escape from criminal sanctions, which were suffered by the relatives, was the verdict of madness. ${ }^{6}$ During a transitional period of approximately three hundred years, starting around the $1500 \mathrm{~s}$ and lasting until the dawn of the modern era, universal condemnation of suicide was contested gradually with the culmination of Enlightenment philosophers openly challenging the practices of legal prosecution of suicides. The resulting contrast between the medieval suicide discourse firmly built on moral codes based on religious authority and the modern concept of suicide formed by the processes of medicalisation, secularisation, and decriminalisation is sharp. Suicide was removed from the realm of metaphysics and both religious and earthly condemnation and set on the field of scientific enquiry, rooted in modern medicine and the social sciences.

As the modern concept of suicide emerged during the long nineteenth century, phenomena such as industrialisation, urbanisation, institutions of democracy, nationalism, and capitalism and the freemarket economy were spreading throughout the Western world and were already seeping into societies on the fringes of Europe, including Finland. Those who studied suicide in the nineteenth century pointed their fingers frequently at the very features that constituted what was understood as modernisation. After all, it was the new institutions of modern nation-states that raised awareness of the occurrence of suicide in the population. One of these new enterprises was the collecting of social statistics, as the gathering of data became part of the nationbuilding process. ${ }^{8}$ For example, in the 1840 s, the Finnish philosopher and statesman Johan Wilhelm Snellman (1806-81) urged Finnish 
officials to collect statistical data to get a better understanding of the Finnish people. Statistics, he believed, offered an in-depth view, not only of the material qualities of a society, but also of the psychological and moral character of its people. ${ }^{9}$ It appears that Snellman was calling for more systematic and in-depth statistical inquiries to supplement the existing mortality statistics, the likes of which, including causes of death, had been collected in Finland since the 1740s. In fact, the Finnish and Swedish birth and mortality statistics are the oldest continuously collected population statistics in the world. ${ }^{10}$ Gathered under the heading of 'moral statistics', the series of numbers representing crimes, suicide, and other forms of deviance consolidated a new way of regarding human behaviour, as just another measurable part of the world. Because of its moral, medical, and juridical aspects, suicide became the focal point of statistical investigations. ${ }^{11}$

In addition to statistics, the emergence of modern, secular, decriminalised suicide was closely linked to the formation and development of the psychiatric profession in the early years of the nineteenth century. Ian Marsh has gone as far as to claim that 'alienists' - the early French psychiatrists - and especially the renowned Jean-Étienne Dominique Esquirol (1772-1840) used the connection between suicide and madness to bolster their professional claims on the domain of mental health. Traditionally, the provision of 'spiritual counselling' (as a form of psychotherapy), as well as broader care for the mentally ill, had been the duty of the religious establishment. ${ }^{12}$ The emerging psychiatric profession, through their contributions to medical and social debates, played an essential part in the formation of the modern conception of suicide, which can be characterised as 'medicalised suicide'.

The discussion of suicide among medical professionals began in France and Britain, and soon spread to other European countries and the rest of the Western world during the first two decades of the nineteenth century. The first scientific enquiries of suicide in Finland were published in the second half of the century (at the time Finland was a Grand Duchy of the Russian Empire, and remained so until independence in 1917). In 1864, psychiatrist Thiodolf Saelan (1834-1921) published his doctoral thesis Om sjelfmordet I Finland I statistiskt och rättsmedicinskt afseende (On Suicide in Finland: A Study in Statistics and Medical Jurisprudence), in which he examined the suicide phenomenon in Finland using statistical data from the past thirty years. Saelan's thesis 
introduced the international methodology of suicide research to Finnish academia. Based on official statistical data, edited by a private statistical enthusiast, ${ }^{13}$ and illustrated by a handful of case descriptions, Saelan's study was in line with its European counterparts. By presenting several sets of statistics, Saelan endeavoured to shed light on various environmental and temporal circumstances as context for the reported causes of suicides. Saelan's study, like the majority of the suicide research written during the nineteenth century, followed a trend of 'cataloguing of causes, ${ }^{14}$ a prominent feature of mid-nineteenth-century French psychiatry. ${ }^{15}$ This was no wonder, as most of Saelan's quotations came from French authors, such as the psychiatrists Esquirol, Jean Pierre Falret (1794-1870), and Alexandre-Jacques-Francois Brierre de Boismont $(1797-1881){ }^{16}$

As Saelan employed moral statistics as his chief instrument of enquiry, he also embraced mid-nineteenth-century determinism as a way to explain the rising suicide rates. Echoing one of the founding fathers of moral statistical research, the Belgian astronomer Adolph Quetelet (1796-1874), Saelan stated that suicide rates were governed by social laws, comparable to the laws of physics. ${ }^{17}$ Quetelet and other early moral statisticians, such as André-Michel Guerry (1802-66), had been impressed by the regularities in statistical data that illustrated forms of behaviour traditionally attributed to free will, for example murder and suicide. Their conclusion was that there had to be something larger than individual volition at work. ${ }^{18}$ These findings contributed to the rise of deterministic social theories, which became an integral part of late nineteenth-century suicide discourse. In Le suicide (1897), today the most famous work on suicide produced during the nineteenth century, the French sociologistÉmileDurkheim(1858-1917) presented his own concept of suicide based on environmental determinism as he formulated his theory of 'suicidogenic currents.'19

The application of statistical data and statistical analysis in suicide research also contributed to the transformation of the meaning of suicide from an act defined by the individual's immorality (in premodern suicide discourse) and insanity (in modern suicide discourse), to a phenomenon with large-scale social significance. The primary concern for the early and the mid-nineteenth-century suicide researchers had been to establish whether or not suicide was to be regarded as a form 
of madness, or at least as a direct result of psychological morbidity. For example, in the 1860s, Saelan had underlined the importance of not assuming that all suicides were committed by the mentally ill, and of distinguishing mad and sane self-killers as separate categories to establish best possible ways to prevent suicides. ${ }^{20}$ In the latter part of the century, the focus shifted towards the social aetiology of suicide. This change was facilitated by the creation of a mass of statistical suicide data. Another major reason for the shift towards epistemology grounded on moral statistical data was the rise of Darwinism in biology, and the introduction of evolutionary thinking into the social and human sciences.

In psychiatry, which had a tremendous significance in the shaping of understandings of modern suicide, Darwin's theory and other evolutionary ideas paved the way for conceptions of mental illness based on biological predisposition. ${ }^{21}$ Simultaneously, the theory of evolution was being taken up by social scientists. Especially through the works of Herbert Spencer (1820-1903), evolutionary thinking was introduced into the emerging sociological perspective of understanding complex systems such as social organisation, and how various characteristics of a society, such as suicide rate, could be understood in terms of natural selection. ${ }^{22}$ The theory of evolution and its applications in the nascent social sciences helped to undermine the conviction that human societies would be remain somewhat unchanged through time. Following social evolutionary thinking, it seemed that human societies were in constant change and that, by analysing the statistics, outcomes could be predicted. In some cases, the outcome could be undesirable if left unchecked. In the eyes of some contemporaries, modernity was seen as a catalyst for various new and harmful behaviours, such as a capitalistic, egocentric way of life, or urban idleness. These changes were thought to be injurious for individual and society alike, and if not addressed, they would spread in the society causing, for example, neurasthenia, mental illness, and suicide at increasing rate. ${ }^{23}$

Anxiety about the course of the evolution of a given society became more pronounced towards the end of the century, as the dark side of evolution - degeneration - entered the discourses of social sciences, medicine, and suicide. ${ }^{24}$ Degeneration provided a theoretical framework in which to express fears of modernity using the language of 
science. The perceived increases in the incidence of suicide, mental illness, prostitution, alcoholism, and crime were explained within the parameters of theories of degeneration, ${ }^{25}$ and, following a circular logic, degenerated individuals were typified by low morality, low intelligence, madness, and devious behaviour. ${ }^{26}$ International competition fanned the fears of degeneration, which, in turn, created social programmes such as psychological testing of children in France and calls for policies to advance birth rates among people of 'good stock' in the UK and other Western countries. ${ }^{27}$ The concern over the future of a nation was directed towards certain parts of the society as the poor and uneducated working classes began to be seen as threats to civilised society. ${ }^{28}$

Due to its political, social scientific, and biological connotations, it is little wonder that the theories of degeneration swept over academia in the wake of evolutionary thinking. According to Ian Dowbigging, for psychiatrists, in particular, the allure of theories of degeneration and evolutionary thinking in general was that they seemed to provide a conceptual framework for explaining the very nature of madness (and suicide) in seemingly empirical and scientific terms by pointing to heredity as the physical cause of insanity. ${ }^{29}$ There were rather obvious reasons for psychiatrists to embrace the theory of degeneration. By the end of the nineteenth century, psychiatrists could not present any meaningful scientific breakthroughs in diagnosing and even less in curing madness, unlike their colleagues in bacteriology, for example. Degeneration theory offered a double-edged sword to psychiatrists, who wanted to be regarded as scientists. ${ }^{30}$

Following the increasingly mechanistic view of many social phenomena, the philosophical implications of presumed social laws became an integral part of explaining why suicide happened. For centuries, suicide had been understood as something that an individual chooses to commit. The perceived statistical regularities in people's behaviour raised doubts over whether such acts as suicide and homicide were in fact voluntary, or were somehow predetermined by social and cultural forces. The mounting statistical data on rising suicide rates provided groundwork for the idea that suicide was an illness of society rather than an outcome of voluntary human behaviour or, in a more modern view, a specific and individualised pathology. ${ }^{31}$ Towards the end of the century, suicide together with madness was increasingly interpreted as a symptom of harmful aspects of modernity, but also as a sign of 
civilisation that separated modern nations from those who were regarded as barbaric races living outside of the Western cultural sphere.

\section{The sickness of civilisation}

The scientific and philosophical debates surrounding the use of social statistics produced a major transformation that restructured the discourse of suicide. These changes became visible in Fredrik Wilhelm Westerlund's 1897 study, as he fine-tuned the statistical analysis of Finnish suicides. Psychiatric considerations played a lesser part in Westerlund's study in comparison to the previous study by Saelan as he attempted to establish a social aetiology of suicide. Westerlund enriched his arguments by employing statistical data from abroad, and by quoting the international authors on suicide, moral statistics, and determinism, such as German moral statistician Adolph Wagner (1836-1917) and philosopher Moritz Wilhelm Drobisch (1802-96), as well as British author Thomas Henry Buckle (1821-62), whose deterministic History of Civilization in England was published in three volumes between 1857 and $1868 .{ }^{32}$ By historically contextualising the changes in suicide statistics, Westerlund sought means for suicide prevention on a national scale. All of these features distanced Westerlund's work from Saelan's research of thirty years earlier. To understand the shift in focus of Finnish suicide research by the end of the nineteenth century, we need to look at one particular author on suicide, who was a major influence on Westerlund's study.

When it comes to late nineteenth-century suicide research, one work stands out for its major influence on subsequent research: the pan-European moral statistical analysis of suicide, Il Suicidio. Saggio di statistica morale comparata by the Italian psychiatrist Enrico Morselli (1852-1929), originally published in 1878. As Maria Teresa Brancaccio points out, what made Morselli's work so important and also so typical for the era was the way that he fused together some of the most popular topics in the human sciences of the late nineteenth century. ${ }^{33}$ Statistics and statistical analysis formed the empirical foundation of Morselli's enquiry. He embraced statistics in general and moral statistics, in particular, as a way of uncovering the social laws that govern human behaviour. Statistics provided a supposedly objective view of the present state and historical development of a society. Furthermore, 
statistical analysis would provide answers to profound questions on the nature of human agency that philosophy had struggled to solve for centuries. For Morselli, the absolute independence of human actions had been refuted by observed statistical regularities in many forms of human behaviour. ${ }^{34} \mathrm{He}$ embraced the notion of determinism wholeheartedly, as he argued that the seemingly most arbitrary deeds, such as suicide, were, in fact, results of social laws that govern the behaviour of each individual. ${ }^{35}$ Morselli's conclusion was a rather typical example of how the increasing interest in collecting and analysing moral statistics fed the debate over freedom of will and determinism intensified by the end of the nineteenth century. ${ }^{36}$

To come up with a universal explanation to interpret and explain his statistical findings on suicide, Morselli turned to evolutionary theories. He argued that psychologists and sociologists should seek the origins of social and psychological phenomena alike from the laws governing the evolution of life, and therefore they should base their arguments on natural laws instead of on idealistic rhetoric or sentimentalism. ${ }^{37}$ From this premise, Morselli formulated an extremely deterministic definition of suicide: 'suicide is an effect of the struggle for existence and of human selection, which works according to the laws of evolution among civilized people. ${ }^{38}$ Those who did not come out of the struggle as victorious suffered from 'some morbid aberration' in their brains and were removed from the survival contest by voluntary death. ${ }^{39}$ As we can see here, Morselli's definition of suicide was not meant to be a universal definition. Instead, his focus was on the suicide phenomenon in modern, 'civilised', societies, where the main source of misfortune and suffering causing suicides (and other individual and social maladies such as madness and prostitution) was the psychologically taxing struggle for existence.

The mechanism of suicide that Morselli outlined was rooted in a psychiatric understanding of nervous illnesses. Morselli argued, echoing the psychiatric and neurological conception of the causes of hysteria and neurasthenia, that in civilised societies the struggle for life manifested itself intellectually instead of through physical violence. ${ }^{40}$ 'The struggle', as Morselli wrote, 'between civilized peoples tends to become still more a struggle of intelligence. ${ }^{, 41}$ Therefore, suicide was more common in civilised and secular societies, as intellectual aspirations were thought to cause strain and damage to the brain and nervous 
system, which then might lead to insanity. The connection between mental illness and suicide had already been made by early nineteenthcentury psychiatrists, especially by Esquirol, although not all agreed with him on this point, and therefore high mental activity was seen as a possible risk factor that could lead to suicide. ${ }^{42}$

According to Morselli, as modern societies became more complex, if the suicide phenomenon were to be left unchecked, suicide rates would continue to increase at the same pace as cultural advancement. This hypothesis was shared by many late nineteenth-century suicide researchers, including the coroner William Wynn Westcott (1848-1925) in England, who had noted in 1885 how it was beyond dispute that 'a preponderant rate of suicide, and a high rate of madness exist in countries the farthest advanced in our modern ideas of civilization. ${ }^{43}$ In the German-speaking world, Alexander von Oettingen argued that materialism of modern civilisation made people weary of life, and his pupil in moral statistical research, Adolph Wagner, argued that Protestantism as a more 'modern' form of Christianity produced more suicides. ${ }^{44}$ On the other side of the Atlantic, William Mathews (1818-1909) came to a similar conclusion in his essay 'Civilization and suicide', published in 1891. Praising Morselli as one of the most brilliant students of suicide, Mathews confirmed that modern civilisation was to blame for the increasing numbers of suicides. ${ }^{45} \mathrm{~A}$ fast pace of living, excitement, and competition were at the centre of nineteenth-century life. 'Express-railway stock wears out far more rapidly ... and man's nervous system is subject to the same law', Mathews wrote, conjuring images of a speeding mechanised lifestyle. ${ }^{46}$ And finally, writing in 1897 - the same year that Westerlund completed his suicide study - Emile Durkheim described the hypercivilization which ... refines nervous systems, making them excessively delicate ... [and] more accessible both to violent irritation and to exaggerated depression. ${ }^{37}$ What we can gather from the aforementioned authors is that changes in the way people lived, as well as changes in their spatial and social environments - brought about by railroads, electricity, and urbanisation - were regarded as explanations for the modern prevalence of suicide. Here suicide is seen as a sign of modernity, and as a disease born out of progress. But how did this perception translate to societies where 'express-railway' and fast-paced urban life were only a rumour heard from those travelling abroad? 
As the quotation at the beginning of this chapter illustrates, Westerlund was well aware of the dissimilarities between his native country and the 'greater nations' of Central and Western Europe, conditions of which had been the subject of the existing literature on suicide. However, as any scholar who strives to create dialogue, he picked up the central concepts of the transnational discourse of suicide and employed them in his analysis of the Finnish suicide data. A logical starting point was to compare rural and urban suicide rates and to see how Finnish statistics answered their international counterparts.

For contemporary observers, the growth of urban centres was one of the most visible signs of modernisation. Unsurprisingly, urbanisation was often one of the prime explanations when the causes of suicide were sought. Urban life, it seemed, was especially plagued by the danger of suicide, while, as one American observer stated. People living in rural areas had no time to think mischievous thoughts of suicidal nature while they were engaged with agrarian activities. ${ }^{48}$ The traditional agrarian way of life was regarded as morally superior to the busier character of urban life, which was generally considered to put a strain on the nerves due to its busier character. ${ }^{49}$ Westerlund, like his international colleagues, considered the comparatively high suicide rates in Helsinki to be caused by an intensified struggle for existence in urban areas. ${ }^{50}$ However, as Finland was quite far behind many of the Western European countries in its level of urbanisation, he thought generally lower Finnish suicide rates to be a result of a less intense struggle for existence. He stated that Finland was spared from the overtly strong influence of degeneration due to the agrarian and less urbanised structure of the society. ${ }^{51}$ Despite this acknowledgement, Westerlund did consider suicide to be a problem for Finnish society, and one that was related to the country's level of modernisation. By looking at the measures that he proposed to prevent Finnish suicides, we get a clearer picture of exactly how suicide and modernisation were connected to each other in Westerlund's reasoning.

In the list of preventative measures, Westerlund placed a strong emphasis on the battle against famine, caused by failure of crops, as a measure to prevent suicides. He made a rather peculiar comparison between the 'struggle for existence' in other more developed nations 
and the impact of crop failures in Finland, arguing that they had a comparable influence on the suicide rates. ${ }^{52}$ Westerlund's Western European colleagues generally viewed 'struggle for existence' in relation to the effects that modernisation had on society, usually targeting urban lifestyle as a way of life that was seen as harmful to moral and even physical well-being. In Finland, however, the 'struggle for existence' was interpreted through a more practical lens. Born in 1844, Fredrik Wilhelm Westerlund had been in his mid-twenties when consecutive failures of crops in Finland caused the famine of 1866-68. The winter of 1866-67 had been unusually cold and the spring of 1867 had come late, as the median temperature in May had been only $+1.8^{\circ} \mathrm{C}$ in Helsinki, almost ten degrees below the average. On top of that, freezing weather in September had destroyed the crops in many parts of the country. Partially due to the slow reaction by the Senate of Finland, international food aid did not reach the country in time, and as a result Finland and especially the Finnish countryside was plunged into a food catastrophe. During these great hunger years, around 150,000 people died from hunger, diseases, and - for a small part - suicide, equating to almost $10 \%$ of the population of $c .1 .7$ million. In the worst-hit areas, the death rate reached $20 \%$ of the population. ${ }^{53}$ The experience was engraved on people's imagination, and it was echoed in art and literature for decades after.

Looking at the suicide statistics of the 1860s, there was in fact an increase of over $40 \%$ in the suicide rate in 1868 , the worst year of famine (see Table 8.1). A growth of similar magnitude in suicide numbers had been experienced in 1848, when in the aftermath of the 1846 crop failure, a cholera epidemic reached Finland. ${ }^{54}$ During the famine, in addition to 'normal' suicides, it was fairly common for an individual who committed suicide to kill one or several family members before killing themselves. Westerlund described several cases of such 'extended' suicides, which he explained were caused by delirium due to typhoid fever and hunger. ${ }^{55}$ Looking at the Finnish statistics, Westerlund saw a very different statistical reality from his European and American colleagues, who were mostly worried about the fast-paced progress of society and the nervous strain it caused.

After the great famine years of the late 1860s, Finland went through a rapid period of industrialisation. The experience of catastrophe partially speeded up the economic progress of the country; the government 
TABLE 8.1 Suicide per 1 million inhabitants in Finland, 1841-90

\begin{tabular}{lllll}
\hline 1841: 36.2 & $1851: 44.3$ & $1861: 44.05$ & $1871: 31.05$ & $1881: 34.57$ \\
$1842: 36.4$ & $1852: 44.6$ & $1862: 40.87$ & $1872: 29.98$ & $1882: 34.54$ \\
$1843: 49.2$ & $1853: 41.4$ & $1863: 38.39$ & $1873: 30.11$ & $1883: 44.73$ \\
$1844: 37.4$ & $1854: 42.3$ & $1864: 42.12$ & $1874: 36.05$ & $1884: 38.53$ \\
$1845: 29.1$ & $1855: 49.0$ & $1865: 47.20$ & $1875: 40.78$ & $1885: 40.30$ \\
$1846: 40.4$ & $1856: 52.0$ & $1866: 47.34$ & $1876: 33.97$ & $1886: 46.01$ \\
$1847: 43.7$ & $1857: 52.0$ & $1867: 42.76$ & $1877: 36.52$ & $1887: 37.75$ \\
1848: $\mathbf{6 0 . 7}$ & $1858: 46.9$ & $\mathbf{1 8 6 8}: \mathbf{6 0 . 7 8}$ & $1878: 38.10$ & $1888: 40.62$ \\
$1849: 43.3$ & $1859: 40.6$ & $1869: 46.57$ & $1879: 32.47$ & $1889: 32.80$ \\
$1850: 45.2$ & $1860: 48.7$ & $1870: 39.58$ & $1880: 27.18$ & $1890: 39.92$
\end{tabular}

Source: F. W. Westerlund, 'Själfmorden i Finland 1861-1895', Bidrag till kännedom af Finlands natur och folk (Helsingfors: Finska VetenskapsSocieteten, 1900), p. 125.

instigated the development of the railroad network to ensure food aid would reach the periphery in cases of future famine, for example. ${ }^{56}$ Between 1870 and 1910, the urban industrial labour force increased from 150,000 to over 600,000 . However, when we look at the structure of the Finnish economy, only $4 \%$ of the population earned their livelihood in industrial occupations in 1870, and even by 1910 the figure had only increased to $14.7 \%$ of the population. ${ }^{57}$ It is fair to say that the Grand Duchy of Finland was distinctly an agrarian society at the dawn of the twentieth century, around the time when Westerlund conducted his suicide study. Wide-scale urbanisation and the curses of the modern lifestyle that were thought to follow in its wake had not yet arrived in Finland. Social and economic circumstances that Westerlund considered as central points of focus of suicide prevention were very different in Finland from, for example, in France or the UK. But, as he noted that suicide and intensified struggle for existence were products of 'laws of nature' that gained their force from social circumstances, by manipulating these very same circumstances humankind could also work to decrease the number of suicides and other social ills. As 'progress gone too far' could hardly have been the cause of suicides in Finland, the development and modernisation of the society on a very basic level, 
such as food production and distribution, was the remedy that Westerlund recommended to combat suicides. ${ }^{58}$ As Finland was still suffering from such societal problems as famine, it becomes understandable why a Finnish suicide researcher asked for more modernity rather than denouncing modernity and progress as the sources of suicide. The situation was almost an exact opposite of other Western nations, where the faster pace of modernisation and the moral debates surrounding various aspects of modern life had directed the attention of suicide researchers to see modernity as something that causes suicides rather than preventing them.

\section{Free-willed progress and its benefits}

While Westerlund agreed with Morselli's conclusion that there was indeed a connection between modernisation and suicide, he disagreed with Morselli's rather strict deterministic outlook on the progress of civilisation and its effects on individual behaviour. He pointed out how the causes of suicide varied between social classes, intellectual causes being typical for the upper echelons of society. More importantly, he argued that the power of determinism varied between the social classes. Committed by intellectually advanced and well-educated individuals (typically doctors, businessmen, scholars, and artisans), suicide could be regarded as a premeditated act, as the higher reaches of society exercised stronger moral freedom. The lower classes, due to generations of manual labour, alcoholism, poor education, and so on, were slaves to environmental determinism. In effect, Westerlund defined two different kinds of suicides: the more common kind was committed by morally inferior people, and it was determined by environment and inherited degeneration. The other kind of suicide was an act of self-sacrifice, to which free individuals sometimes had to resort. A wife caring for her sick husband knowing that she might also get ill and die in the process was one rather ambiguous example given by Westerlund..$^{59}$

Westerlund was far from being alone as he distanced himself from the excessively deterministic interpretation of statistics. Although Westerlund was mainly influenced by Morselli's work, which exhibited a deterministic combination of materialism and Darwinism, he also studied the works of Oettingen and Wagner. Both German statisticians, especially 
after the former had convinced the latter, distanced themselves from rigid determinism and advocated social reforms as preventative measures to combat suicide. ${ }^{60} \mathrm{~A}$ similar stance had been voiced in the early 1890 s by Westerlund's compatriot, a Member of Parliament, and the founding father of the cooperative movement in Finland, Hannes Gebhardt (1864-1933). In his article 'Siveellisyystilastot ja ihmistahdon vapaus' ('Moral statistics and free will'), published in 1891, Gebhardt strongly rejected fatalistic implications of deterministic thinking. By pointing out correlations between suicide, mental illness, and other misfortunes, Gebhardt argued that with further social progress the freedom of individuals would increase and it would become possible to fix societal deficiencies that drove people into madness and suicide. ${ }^{61}$ The only way to improve society was through the use of reason and rational planning of society; this was the approach taken by Westerlund and Gebhardt. Without freedom of will, deliberate societal development was considered impossible. ${ }^{62}$ For those who distanced themselves from determinism, deliberate development of society was possible and also necessary to decrease the number of suicides. ${ }^{63}$ Statistics would provide insight into the past and the present state of society, but they did not predict the future, and said nothing about ever-present laws that would govern human behaviour, as yet another Finnish statistician, Anders Boxtröm (1846-1906) had noted in $1891 .^{64}$

\section{Conclusion}

It was clear that the lack of modernisation and progress - as in the case of the nation's inability to provide food aid in the case of crop failure - could also be considered as a cause of suicides, especially among the lowest classes of the society. Writing from a less developed country such as Finland, which had social problems due to lack of progress, Westerlund perceived suicide as a tragic outcome of vastly different scenarios, many of which had nothing to do with high levels of social progress, sophisticated brain development, or modern civilisation. ${ }^{65}$ Consequently, Westerlund, with a critical attitude towards tying suicide and modernisation together, contested one of the most repeated statements of nineteenth-century suicide discourse, according to which only civilised people would commit suicide. By pointing out that even societies that had only just begun to go through modernisation produced 
suicides, Westerlund outlined suicide as an act universal to all humankind. He illustrated the argument by describing how many authors regarded suicide exclusively as a sign of modernity, as a privilege of culturally refined people, and therefore unheard of among the 'barbaric races'. Rather laconically, he pointed out that it was not uncommon for women in India to follow their husbands to death, or for a Chinese official to 'cut his stomach open at the slightest occasion of dishonour.' ${ }^{66}$ It seems that Westerlund was here conflating Chinese customs with the Japanese practice of harakiri, but it is noteworthy that he saw suicide as a part of all cultures instead of as a phenomenon typical of a certain developmental stage of human society.

As we have seen, the introduction of modern suicide research presented the idea of suicide as a sickness of modernity. Statistical data and evolutionary theories provided suicide researchers with a theoretical framework with which to explain the increasing rates of suicide in civilised countries, and the bond between suicide and modernity was forged even more strongly by the end of the nineteenth century. But even as the fear of modernity and urban degeneration ruled suicide discourse in the most materially advanced nations, the fact remained that suicides were also committed in less-developed societies, and even outside of the Western cultural sphere. In fact, Westerlund attributed the Finnish suicide epidemics of the 1860s to the material underdevelopment of Finland. As mentioned in the Introduction of the present volume, one of the great theorists of the 'disease of modernity', George Miller Beard, attributed mental exhaustion, a typical cause of suicide, to such elements of progress as steam power and telegraphy. Ironically, the poor means of communication between coastal and inland regions was seen as one of the primary causes of the great famine and increase in suicide in Finland in the 1860 s by contemporaries. Modernity, when it was regarded in the light of suicide statistics, became an ambiguous concept, which had to be interpreted in the local context.

For an observer like Westerlund, writing outside of the heart of modernisation, to see suicide as a universal human behaviour gave him an opportunity to critically evaluate dominant perceptions of suicide. As it turned out, the widely popular concept of the intimate connection between suicide and modernity was itself a product of modernisation. It was partially based on statistical findings as to what was happening in societies experiencing urbanisation, industrialisation, and other 
aspects of modernity. But the way these findings were interpreted was to aggrandise the material and cultural development of 'civilised' nations and to emphasise the gap between them and those which were regarded as cultures without modern civilisation.

\section{Notes}

1 'I större länder, där den stora mängder individer skapar mera invecklade förhållanden och flere sociala motsatser, större rikedomar och mera elände, högt stående intelligens och högre antal degenerade individer, kan väl kampen mot själfmorden ... stundom förefalla hopplös, ock låta betraktaren anse dem som oundvikliga följder af en grym determinism.' F. W. Westerlund, 'Själfmorden i Finland 1861-1895', Bidrag till kännedom af Finlands natur och folk (Helsingfors: Finska Vetenskaps-Societeten, 1900), 274.

2 H. Kushner, Self-Destruction in the Promised Land: A Psychocultural Biology of American Suicide (New Brunswick: Rutgers University Press, 1989); H. Kushner, 'Suicide, gender, and the fear of modernity in nineteenth-century medical and social thought', Journal of Social History, 26:3 (1993), 461-90; H. Kushner, 'Suicide, Gender and the Fear of Modernity', in J. Weaver and D. Wright (eds), Histories of Suicide (Toronto: University of Toronto Press, 2009), 19-52.

3 E. Leuf, 'Low morals at a high latitude? Suicide in nineteenth-century Scandinavia', Journal of Social History, 46:3 (2013), 1-16 (p. 10).

4 Kushner, Self-Destruction in the Promised Land, 11; J. Watt (ed.), From Sin to Insanity: Suicide in Early Modern Europe (Ithaca, NY: Cornell University Press, 2004).

5 G. Minois, History of Suicide: Voluntary Death in Western Culture (Baltimore, MD: Johns Hopkins University Press, 1999), 45-9. See also A. Hooff, From Autothanasia to Suicide: Self-Killing in Classical Antiquity (London: Routledge, 1990).

6 A. Murray, Suicide in the Middle Ages (Oxford: Oxford University Press, 1999), vol. 1, p. 170; H. Klemettilä, Keskiajan julmuus (Jyväskylä: Atena Kustannus, 2008), 181-5.

7 Minois, History of Suicide, 228-36, 250-3.

8 Leuf, 'Low morals', 1.

9 J. V. Snellman, 'Om Finsk Statistik', in J. V. Snellman Samlade Arbeten IV 1844-1845 (Helsingfors: Statsrådets Kansli, 1994), 544.

10 G. Luther, Suomen tilastotoimen historia vuoteen 1970 (Helsinki: WSOY, 1993), 22-3. 
11 U. Baumann, Vom Recht auf den eigenen Tod (Weimar: Verl. Hermann Böhlaus Nachf., 2001), 220; D. Lederer, 'Sociology’s “One Law”: moral statistics, modernity, religion, and German nationalism in the suicide studies of Adolf Wagner and Alexander von Oettingen', Journal of Social History, 46:3 (2013), 688-9.

12 I. Marsh, Suicide: Foucault, History and Truth (Cambridge: Cambridge University Press, 2010), 100-2, 115-16.

13 In Finland, as in many other countries, publication of statistics was initially in the hands of private enthusiasts before public authorities began to produce official regularly appearing statistical publications. The Central Statistical Office of Finland was founded in 1865, one year after Saelan published his dissertation. Luther, Suomen tilastotoimen historia, 38-41.

14 See M. Myllykangas, Rappeutuminen, tiedostamaton vai yhteiskunta? Lääketieteellinen itsemurhatutkimus Suomessa vuoteen 1985 [Degeneration, unconscious, or society? Medical suicide research in Finland until 1985, doctoral thesis] (Oulu: Universitatis Ouluensis, B 120, 2014), 45-6.

15 I. Dowbiggin, Inheriting Madness: Professionalization and Psychiatric Knowledge in Nineteenth-Century France (Berkeley: University of California Press, 1991), 29-30.

16 M. Myllykangas, 'The History of Suicide Prevention in Finland, 1860s-2010s', in D. Kritsotaki, V. Long, and M. Smith (eds), Preventing Mental Illness: Past, Present, Future (London: Palgrave Macmillan, 2019), 151-70 (p. 153).

17 T. Saelan, Om sjelfmordet I Finland I statistiskt och rättsmedicinskt afseende (Helsingfors: J. C. Frenckell \& Son, 1864), 5.

18 J. Kivivuori, Discovery of Hidden Crime (Oxford: Oxford University Press, 2011), 31, 40; T. Porter, The Rise of Statistical Thinking 1820-1900 (Princeton, NJ: Princeton University Press, 1986), 49.

19 J. Weaver, A Sadly Troubled History: The Meanings of Suicide in the Modern Age (Montreal: McGill-Queen's University Press, 2009), 47. According to Jack D. Douglas, Durkheim's 'suicidogenetic currents' that produced suicides were, in turn, caused by imbalance 'between the two sets of opposing forces' (egoism/altruism and anomie/fatalism). J. Douglas, The Social Meaning of Suicide (Princeton, NJ: Princeton University Press, 1967), 57.

20 Saelan, Om sjelfmordet, 63.

21 P. Pietikäinen, Madness: A History (London: Routledge, 2015), 125.

22 R. Smith, Between Mind and Nature: A History of Psychology (London: Reaktion Books, 2013), 59-60.

23 M. Jackson, The Age of Stress: Science and the Search for Stability (Oxford: Oxford University Press, 2013), 24-36. 
24 On degeneration theory in nineteenth-century psychiatry, see Pietikäinen, Madness, 126-9; A. Scull, Madness in Civilization: A Cultural History of Insanity from the Bible to Freud, from the Madhouse to Modern Medicine (Princeton, NJ: Princeton University Press, 2015), 243-6.

25 Daniel Pick has argued that degeneration doctrine was never formalised as a single, coherent theory, but instead was redefined and restructured multiple times by different authors. It is therefore more accurate to talk about degeneration theories in the plural or of more general 'degeneration thinking. D. Pick, Faces of Degeneration: A European Disorder, c. 1848-c. 1918 (Cambridge: Cambridge University Press, 1989), 7.

$26 \mathrm{H}$. Rimke and A. Hunt, 'From sinners to degenerates: the medicalization of morality in the 19th century', History of the Human Sciences, 15:1 (2002), 59-88 (p. 73).

27 Smith, Between Mind and Nature, 107, 112.

28 A. Herman, The Idea of Decline in Western History (New York: Free Press, 1997), 110-11.

29 Dowbiggin, Inheriting Madness, 5-6.

30 Even though degeneration theory offered tools to conceptualise madness, the concept of inherited mental illness left little room for therapeutic measures. P. Pietikäinen, Neurosis and Modernity: The Age of Nervousness in Sweden (Leiden: Brill, 2007), 78-81.

31 See e.g. E. Morselli, Suicide: An Essay on Comparative Moral Statistics (New York: D. Appleton and Company, 1882), 15-16.

32 See Myllykangas, Rappeutuminen, 69, 77.

33 M. Brancaccio, "The fatal tendency of civilized society": Enrico Morselli's suicide, moral statistics, and positivism in Italy', Journal of Social History, 46:3 (2013), 700-15 (p. 700).

34 E. Morselli, Suicide, 16.

35 Brancaccio, 'Fatal Tendency', 700-1.

36 Weaver, A Sadly Troubled History, 61.

37 Morselli, Suicide, 355.

38 Ibid., 354.

39 Ibid., 361-2.

40 The diagnosis of 'neurasthenia' was introduced in 1880 by American neurologist George Beard (1839-1883). The disease was thought to plague the upper-middle-class businessmen and others who strained their mental capacity to the extreme. D. Schuster, Neurasthenic Nation: America's Search for Health, Happiness, and Comfort, 1869-1920 (New Brunswick: Rutgers University Press, 2011).

41 Ibid., 358. 
42 Esquirol's countryman, for example, psychiatrist Pierre-Egiste Lisle disagreed with Esquirol completely and argued that suicide was never solely caused by madness. I. Hacking, The Taming of Chance (Cambridge: Cambridge University Press, 1990), 71. Saelan agreed with Lisle and stated that there were many instances, historical and present, where suicide could not be attributed to mental illness. Myllykangas, Rappeutuminen, 50-1.

43 W. Westcott, Suicide: Its History, Literature, Jurisprudence, Causation, and Prevention (London: H. K. Lewis, 1885), 81.

44 Lederer, 'Sociology's “One Law”', 690-3.

45 W. Mathews, 'Civilization and suicide', The North American Review, 152:413 (1891), 470-1, 477.

46 Ibid., 482-3.

47 E. Durkheim, Suicide: A Study in Sociology (London: Routledge \& Kegan Paul, 1970), 323.

48 Kushner, Self-Destruction, 42-3.

49 The debate over the effects of urbanisation on suicide rates continued among suicide researchers and psychiatrists in general well into the twentieth century. For example, as Finland went through yet another phase of modernisation in the 1960s, psychiatrists were worried about whether population moving into urban areas would experience more mental disorders and commit more suicides. M. Myllykangas, 'The social engineering of suicide: psychiatric epidemiology and suicide research in Finland in the 1960s and 1970s', Medizinshistorisches Journal, 54:2 (2019), 145-68.

50 Westerlund, 'Själfmorden', 195.

51 Ibid., 274

52 Ibid., 273.

53 O. Turpeinen, Nälkä vai tauti tappoi? Kauhunvuodet 1866-1868 (Helsinki: Suomen historiallinen seura, 1986), 22; M. Klinge, Keisarin Suomi (Espoo: Schildts Miktor, 1997), 239.

54 Westerlund, 'Själfmorden', 127; H. Vuorinen, Tautinen historia (Tampere: Vastapaino, 2002), 124-6.

55 Westerlund, 'Själfmorden', 128-9.

56 Klinge, Keisarin Suomi, 240-2.

57 V. Rasila, Torpparikysymyksen ratkaisuvaihe (Helsinki: Suomen Historiallinen Seura, 1970), 18.

58 Westerlund, 'Själfmorden', 273-4.

59 Ibid., 271.

60 Baumann, Vom Recht, 222. 
61 H. Gebhardt, 'Siveellisyystilastot ja ihmistahdon vapaus', Valvoja 21 (1891), $152-3,160-1$.

62 Adolph Quetelet had already argued that by uncovering social laws by the use of statistics humanity could improve, instead being forced to obey the social laws as if they were as universal as the laws of physics. C. Emsley, Crime, Police, and Penal Policy: European Experiences 1750-1940 (Oxford: Oxford University Press, 2007), 120.

63 Westerlund, 'Själfmorden', 273-4.

64 A. Boxtröm, Jemförande befolknings-statistik: med särskildt afseende å förhållandena I Finland (Helsingfors: G. W. Edlund, 1891), 11.

65 Myllykangas, 'Suicide Prevention', 156-7.

66 'eller i Kina, hvarest höga embetsmaän ej sällan rista upp sin mage, då deras ära fått någon flack'. Westerlund, 'Själfmorden', 227. 